\title{
EPIDEMIOLOGY OF LUNG CANCER
}

\author{
Helena Kollárová, Vladimír Janout, Luděk Čížek
}

Department of Preventive Medicine, Faculty of Medicine, Palacký University, Hněvotínská 3, 77515 Olomouc

Received: September 26, 2002

Key words: Lung cancer / Epidemiology / Risk factors

This review article presents lung cancer epidemiology, describing main epidemiologic characteristics including epidemiological situation in cancer incidence, mortality and survival in Europe in comparison with situation in the Czech Republic. Influence of environmental and life style risk factors like smoking, passive smoking, risk factors of work environment, ionizing radiation, air pollution, nutrition and genetic and hormonal factors are discussed.

\section{INTRODUCTION}

At present, primary lung cancer is a worldwide problem. During the last fifty to sixty years, the incidence of this illness has increased dramatically owing to the increasing prevalence of smoking, urbanization and environment pollution.

Lung cancer is now the most frequent malignant tumorous illness in men in most European countries and is increasing in women as well. Annually, more than 1 million people around the world die from the lung cancer and the incidence is increasing, especially in developing countries ${ }^{1,2}$. Although many etiological factors have been known for years, only during last few years preventive and antismoking programs have been started and that only in some countries. Lung cancer is an illness with a long latency and even with recognizing the causing factors and with knowledge of modern medical procedures, an increase of this illness can be expected in near future, especially in the female population.

\section{SITUATION IN EUROPE}

In 1990, approximately 270,000 cases of the lung cancer were diagnosed. With people getting older, the probability of getting lung cancer increases by $4-12 \%$ among European men and by $0.5-3 \%$ among European women, depending on the country. On average, one out of 10-15 European men and one out of 80-90 European women gets the lung cancer before the age of 75 as long as his/her death is not caused by something else. Considering that the incidence of the lung cancer in most of the European countries has an increasing tendency, the risk of getting this illness for young people increases as well. If a fundamental change in risk factors does not occur, after year 2000 , we can expect annually 300,000 cases of lung cancer in Europe ${ }^{3}$.

In Great Britain, where until 1970 an increase of lung cancer death rate had been experienced, the increase has leveled off and after a period of plateau, the lung cancer death rate decreased. In comparison, in South European countries, despite a lower death rate, a rapid increase in the lung cancer death rate has been noted in the recent past. In Central European countries, even in the fifties, the death rate was relatively high and since that time, we have been noticing a steady moderate increase in the lung cancer death rate. In Belgium and Holland, the lung cancer death rate was higher than in other countries, and lately, the lung cancer death rate in these countries has been higher than in Great Britain. Among women, the lung cancer death rate in all monitored European countries has been increasing. The highest values are being noticed in Great Britain, Ireland and Denmark. In central and southern Europe, the incidence is still low and varies in the range of 2-5 women out of 100,000 annually. Taking into consideration that among young women, the population prevalence of smoking is increasing, a dramatic increase in lung cancer can be expected in southern and central Europe within the next 2-3 decades ${ }^{3}$. (Tab. 1, Graph 1, $2,3,4)$ 
Table 1. Estimate of trachea and lung malignant tumours incidence in selected areas of Europe in 2000 - age standardized incidence (world standard).

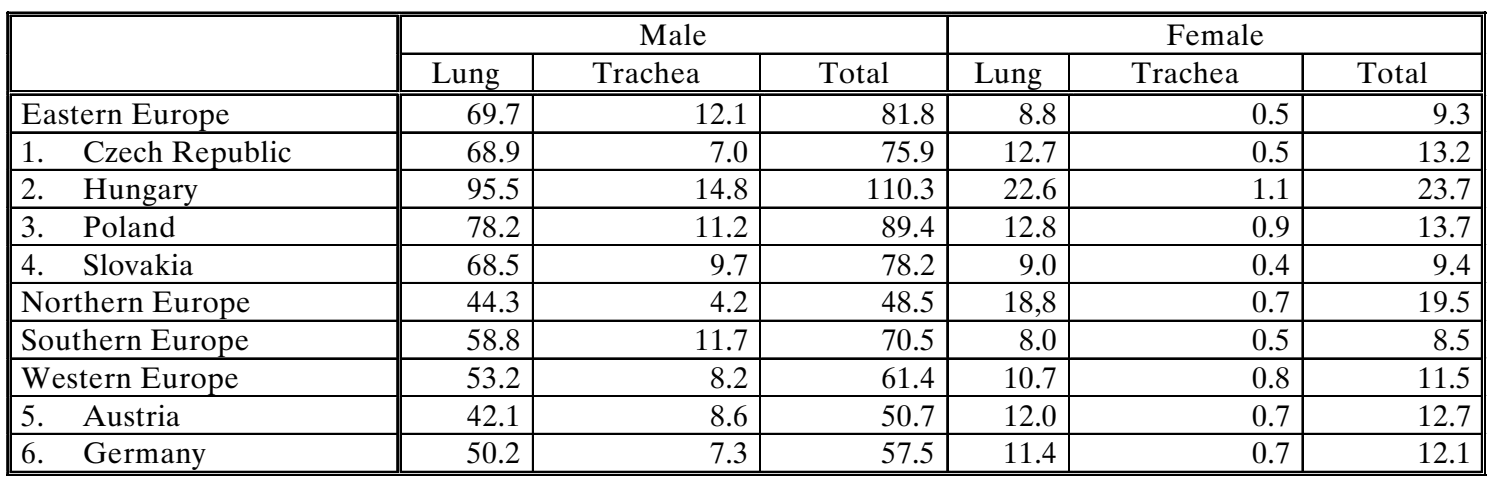

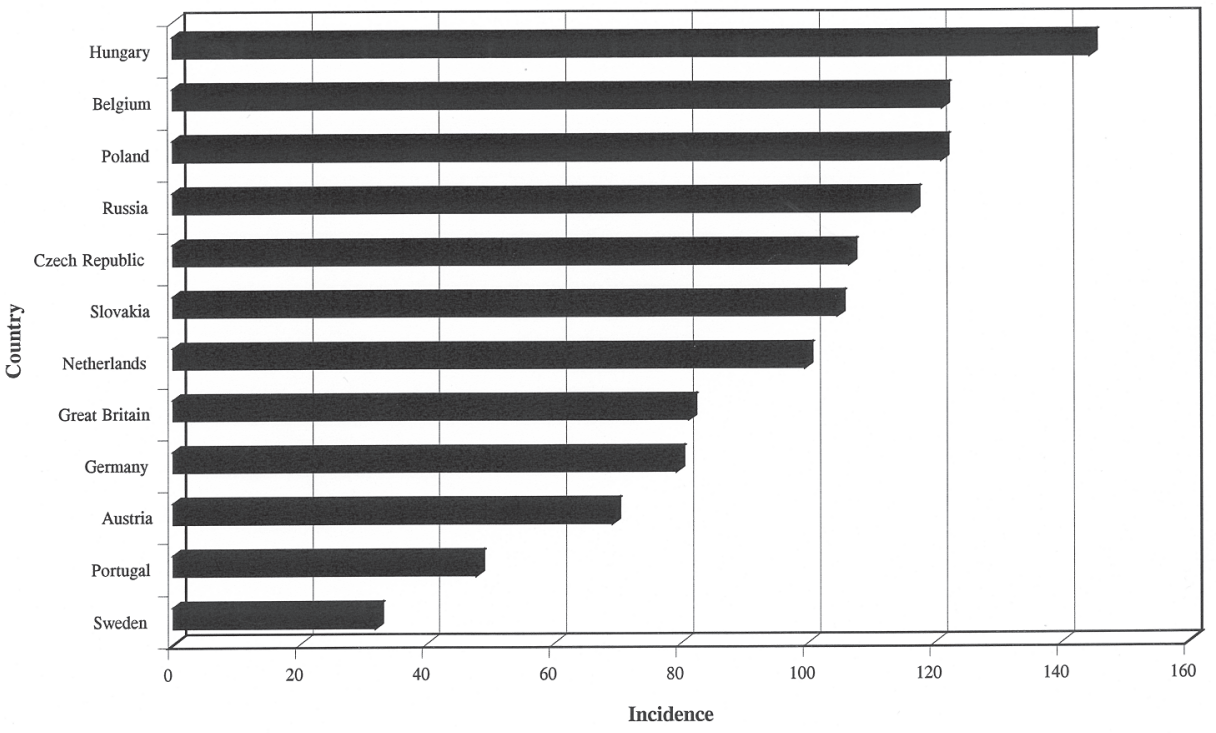

Graph 1. Age standardized lung cancer incidence in some European countries in 1995 - male

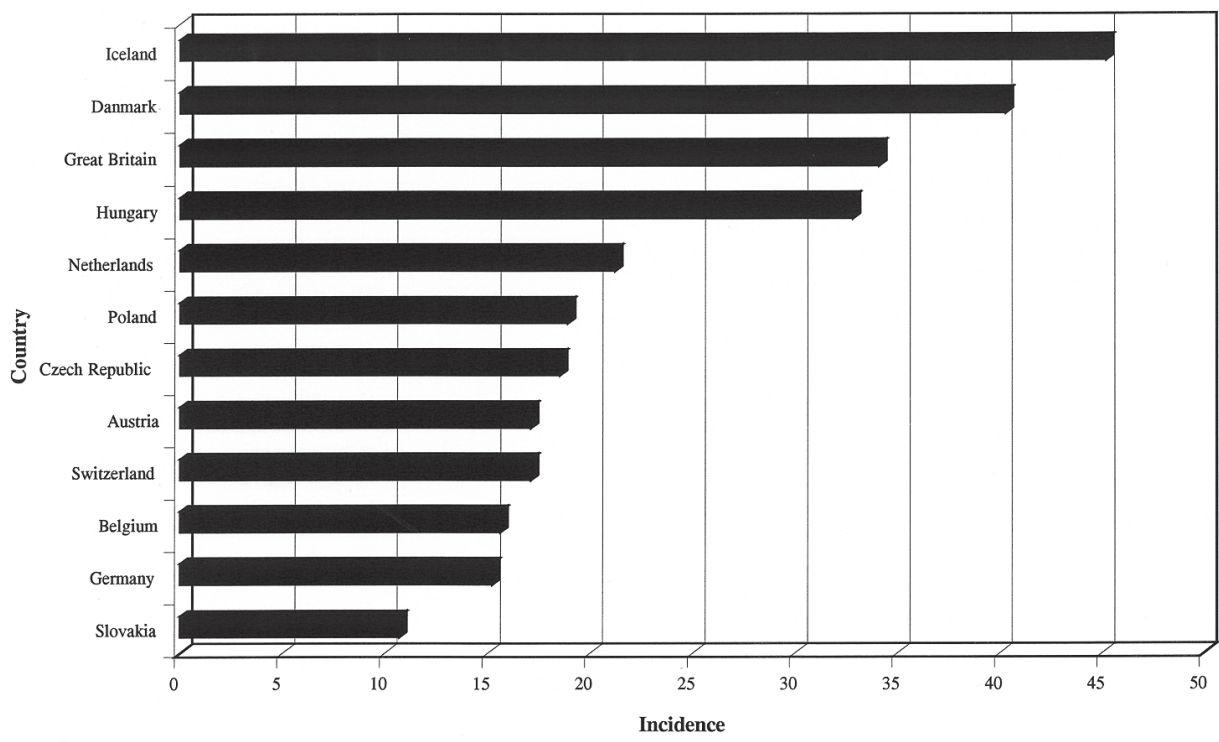

Graph 2. Age standardized lung cancer incidence in some European countries in 1995 - female 


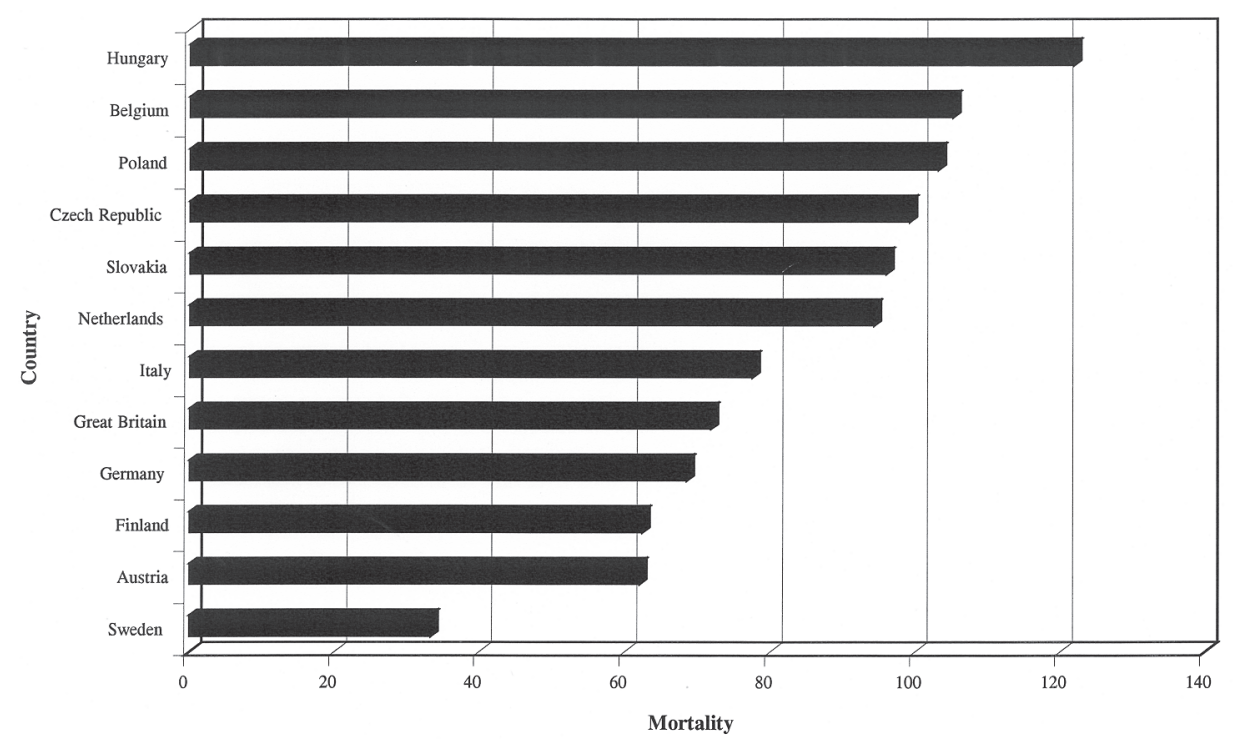

Graph 3. Age standardized lung cancer death rate in some European countries in 1995 - male

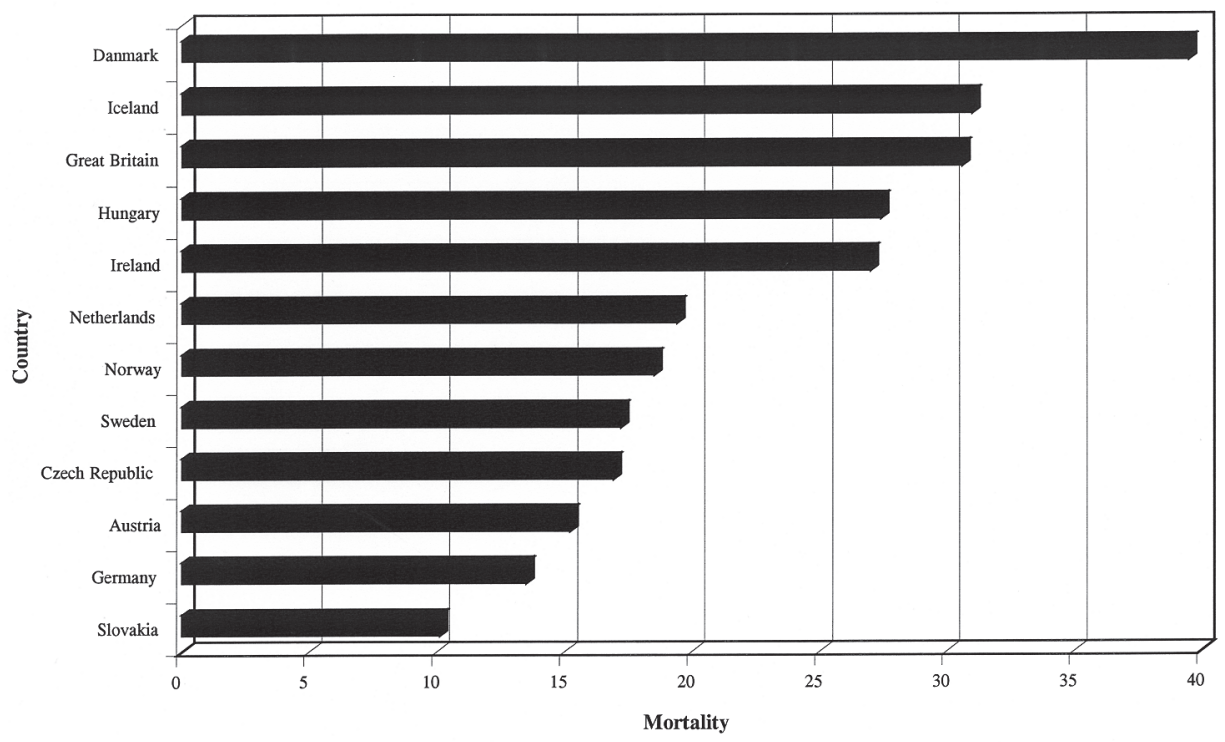

Graph 4. Age standardized lung cancer death rate in some European countries in 1995 - female

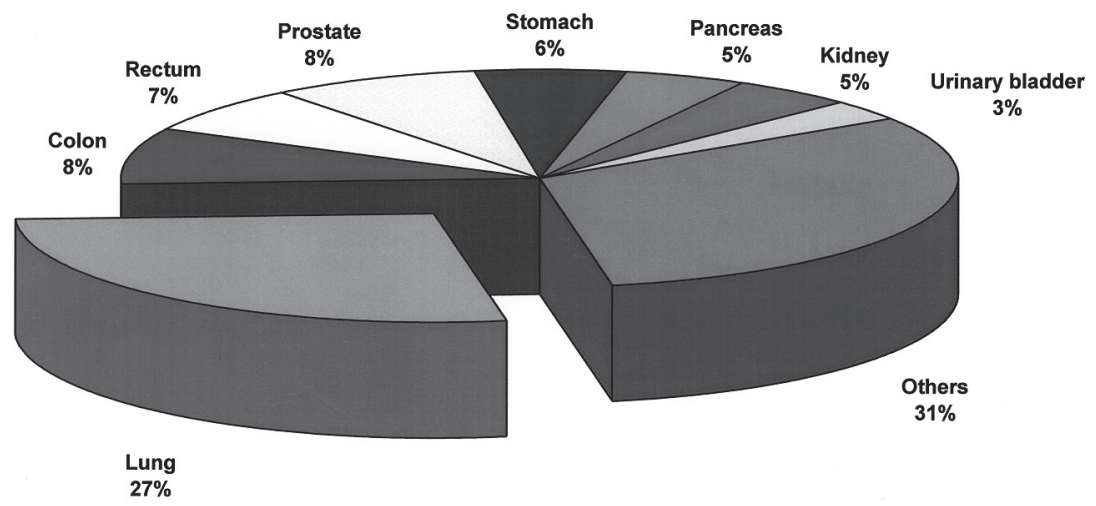

Graph 5. Neoplasm death rate by localities in the Czech Republic in 1999 in \% - male 


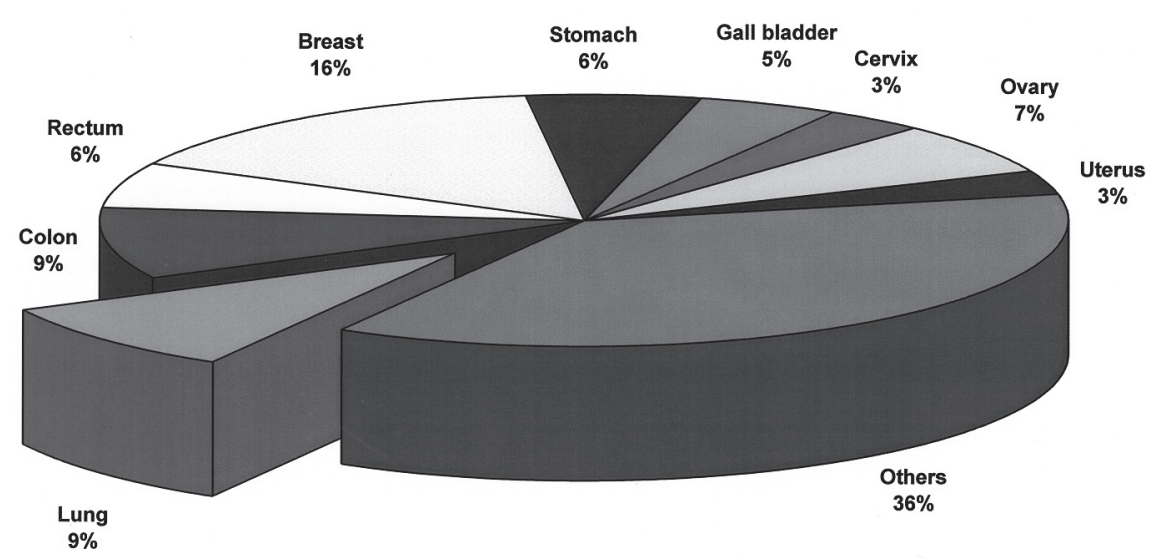

Graph 6. Neoplasm death rate by localities in the Czech Republic in \%-female

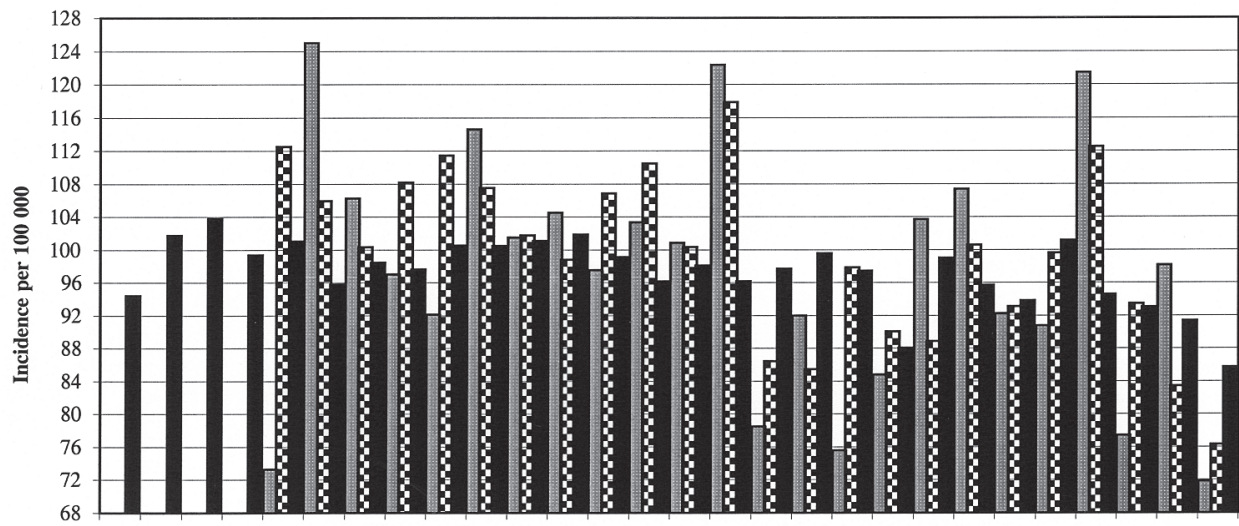

के के की

Year

ECITY OLOMOUC EDISTRICT OLOMOUC $\quad$ ECZECII REPUBLIC

Graph 7. Lung cancer incidence - male

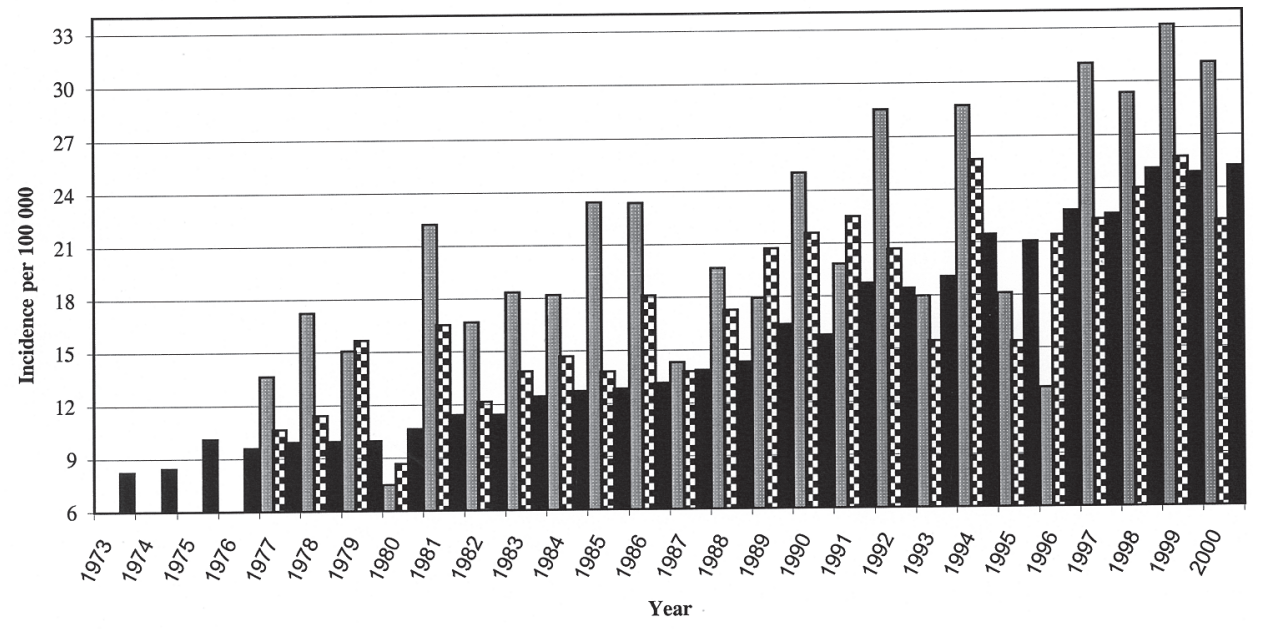

घCITY OLOMOUC

EDISTRICT OLOMOUC

CZECH REPUBLIC 


\section{SITUATION IN CZECH REPUBLIC}

In 1999, in Czech Republic, 56884 malignant tumorous illnesses and tumours "in situ" have been reported, which, if prorated, means 570.1 malignant tumorous illnesses for 100,000 men and 537.2 malignant tumorous illnesses for 100,000 women. The number of the lung cancer cases has a moderately increasing trend, caused by a steady increase in number of illnesses in women, which corresponds to the overall world situation $^{4}$. (Graph 5, 6)

\section{INCIDENCE}

In 1999, in Czech Republic, 4,447 (88.9/10 0,000) cases of lung cancer in men were reported, which indicates stagnation or perhaps small decrease in this illness. In women, 1,181 new lung cancer cases (22.4/ $100,000)$ were reported, which indicates a small incidence increase in comparison with the previous year ${ }^{4}$. (Graph $7,8)$

\section{Mortality}

Death rate from malignant tumorous illnesses is considered an important yardstick in the struggle against malignant tumorous illnesses. In the Czech Republic, lung cancer is a more frequent cause of death than any other malignant tumorous illness. The death rate of lung cancer in men after the $2^{\text {nd }}$ world war has been steadily increasing. In 1950-1967 the death rate rose almost ten times ${ }^{5}$ and in the second half of the nineteen eighties the lung cancer death rate in men in the Czech Republic remained the highest, worldwide ${ }^{6}$. After peaking out in 1986, we have been noticing a decreasing trend.

Until mid nineteen seventies, the lung cancer death rate in woman was at low level values and 10-12 times lower than the rate in men. Since that time, the lung cancer death rate among women has been steadily increasing and at present it is only 6 times lower than the rate in men and the difference is decreasing.

In 1998, in the Czech Republic, 4,298 (85.8/100,000) men and 1,135 $(21.5 / 100,000)$ women died of the lung carcinoma, which , compared with the worldwide standard, is 61.0 men out of 100,000 people and 11.5 women out of 100,000 people?

According to the estimate, by 2009, we can expect a decrease in the death rate in men, especially in the $40-60$ age group. On the other hand, a steady increase is still expected in women in all age groups ${ }^{8}$.

In men, lung cancer mortality is in the 1st place, in women in the second place, although lung cancer incidence among women is in the $6^{\text {th }}-7^{\text {th }}$ place. This can be explained by high lethality and relatively short survival time. This is the reason why the death rate is a an excellent indicator on which we can use to draw conclusions regarding incidence changes ${ }^{9}$. (Graph 9, 10)

\section{Survival time}

Most people who get lung cancer, succumb to this illness. Five year survival time falls into 10 to $13 \%$ range ${ }^{10}$.

The survival time also depends on the histological type; the small cell lung cancer, five year survival time can be expected only in $5 \%$ patients, while with the localized lung cancer, up to $46 \%$ patients $^{11}$. (Graph $11,12)$.

\section{RISK FACTORS, ETIOLOGY}

\section{Smoking}

Smoking is a risk factor contributing to development of a number of illnesses ${ }^{12}$.

In 1920's and 30's, there was, especially in U.S.A., a tremendous increase in the lung cancer and, based on clinical observations, suspicion arose that smoking could be the inducing factor. A number of studies followed $^{12,13,14,15}$, which confirmed the causal relation between cigarette smoking and developing tumorous illnesses, especially lung cancer.

In 1979, the International Agency for Research on Cancer estimated, that the proportion of lung cancer death caused by smoking is $91.5 \%$ in men and $78.5 \%$ in women ${ }^{10,16}$, with the estimates for England and Wales in 1981 even higher, reaching $94 \%$ values in men and $80 \%$ in women ${ }^{12}$.

Similarly, the estimates for Czech Republic in 1990's were approximately $94 \%$ for men and $52 \%$ for women ${ }^{17}$.

Low estimate for women was due to the smaller percentage of women smokers during previous decades in the female population in Czech Republic, as well as in other central and east European countries ${ }^{18}$.

Cigarette smoking is a very serious carcinogenic factor. Cigarettes possess a concentrate of quite a few known genotoxic and carcinogenic agents. Tobacco smoke is a mixture of four to five thousand chemical substances, where the main component is nicotine, but it consists also of other irritative substances like acrolein, aldehydes, ammonia, carbon monoxide, hydrocyanic acid, nitrogen oxides, sulphur oxides, mutagens and approximately 60 carcinogenic agents, aromatic hydrocarbons, aromatic amines, nitrosamines, benzene, cadmium, arsenic, polonium 210 and others ${ }^{19}$. In the metabolic transformation many of these chemical substances, an increase of mutagenic and carcinogenic effects develops, the target tissues and organs sustain oxidation damage and these oxidants create numerous covalent links with DNA. Tobacco smoke consists of the main stream, which is inhaled and partially exhaled by the smoker, and the secondary stream, which is more concentrated, depending on the combustion temperature. A freely burning cigarette stub has a temperature about 300 to $400{ }^{\circ} \mathrm{C}$, during inhaling about $1,000{ }^{\circ} \mathrm{C}^{19,20}$. The amount of inhaled substance is higher in the case of a smoker, but exposure in the case of a non-smoker is 


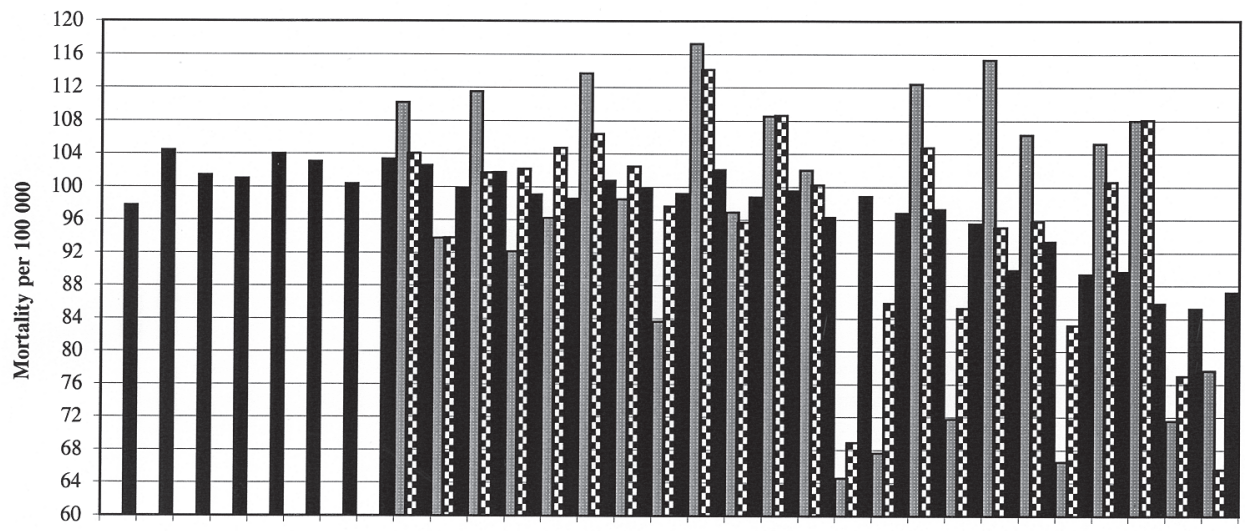

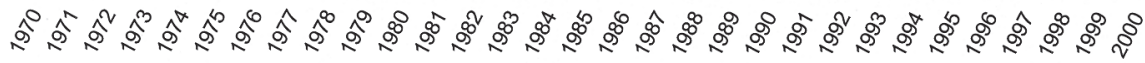

Year

\begin{tabular}{|ll|}
\hline घCITY OLOMOUC & EDISTRICT OLOMOUC
\end{tabular}

Graph 9. Lung cancer mortality - male

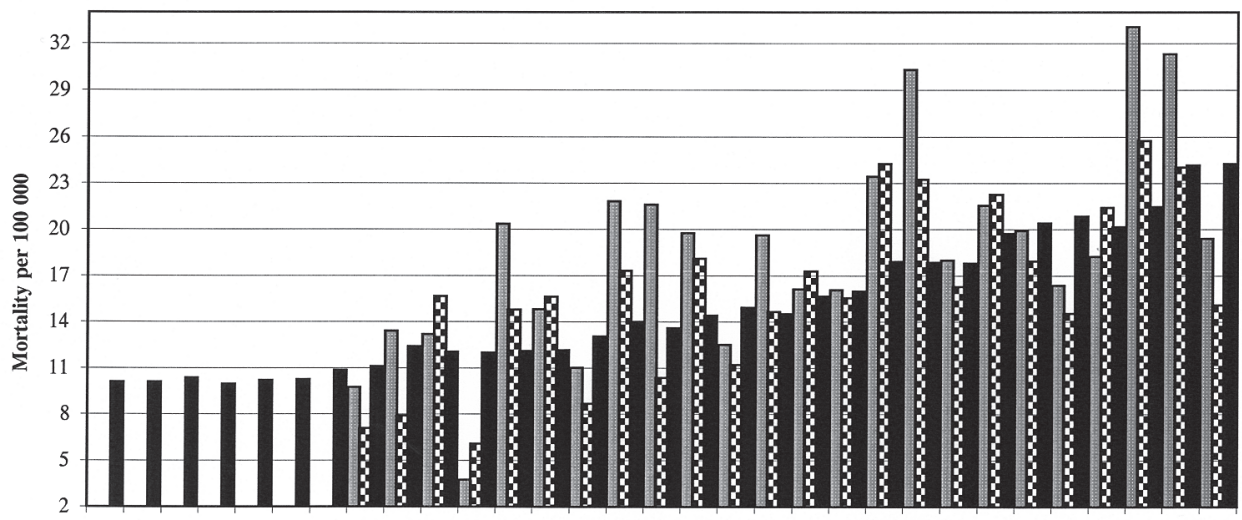

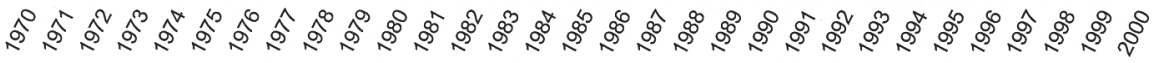

Year

GCITY OLOMOUC $\quad$ EDISTRICT OLOMOUC $\quad$ ECZECH REPUBLIC

Graph 10. Lung cancer mortality - female

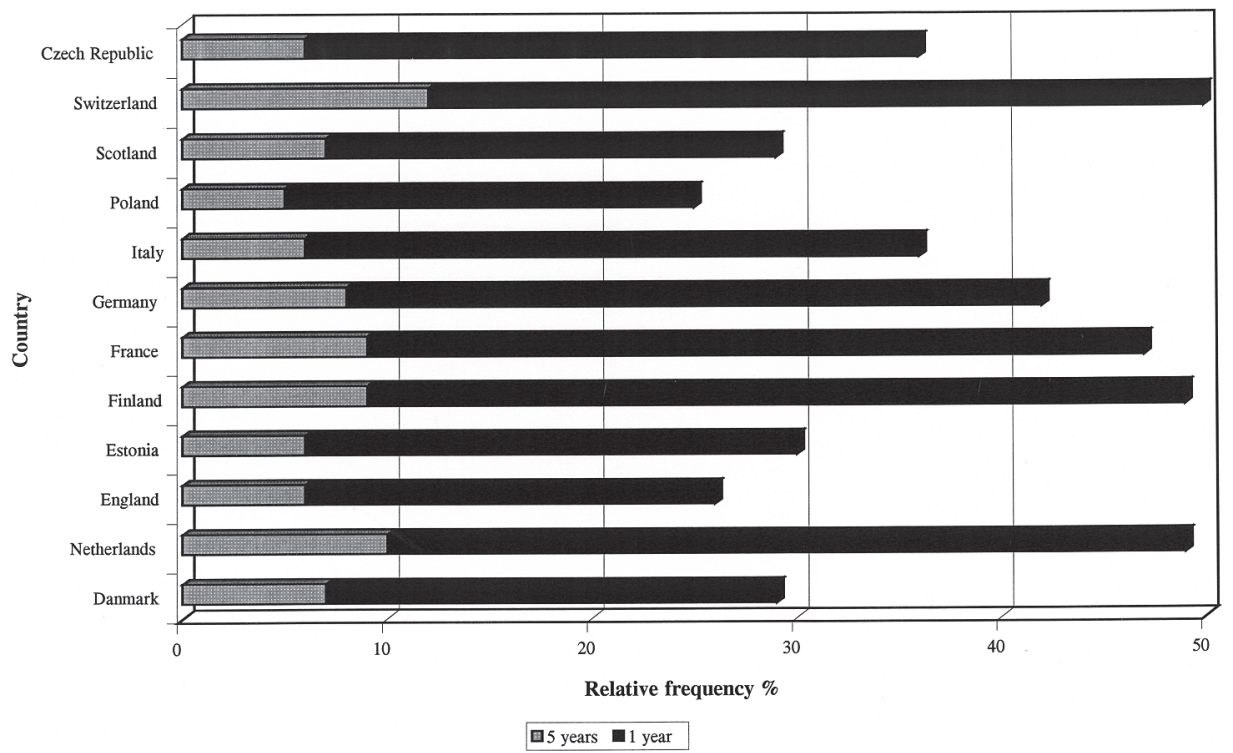

Graph 11. Age standardized lung cancer survival time in some European countries in 1995 - male 


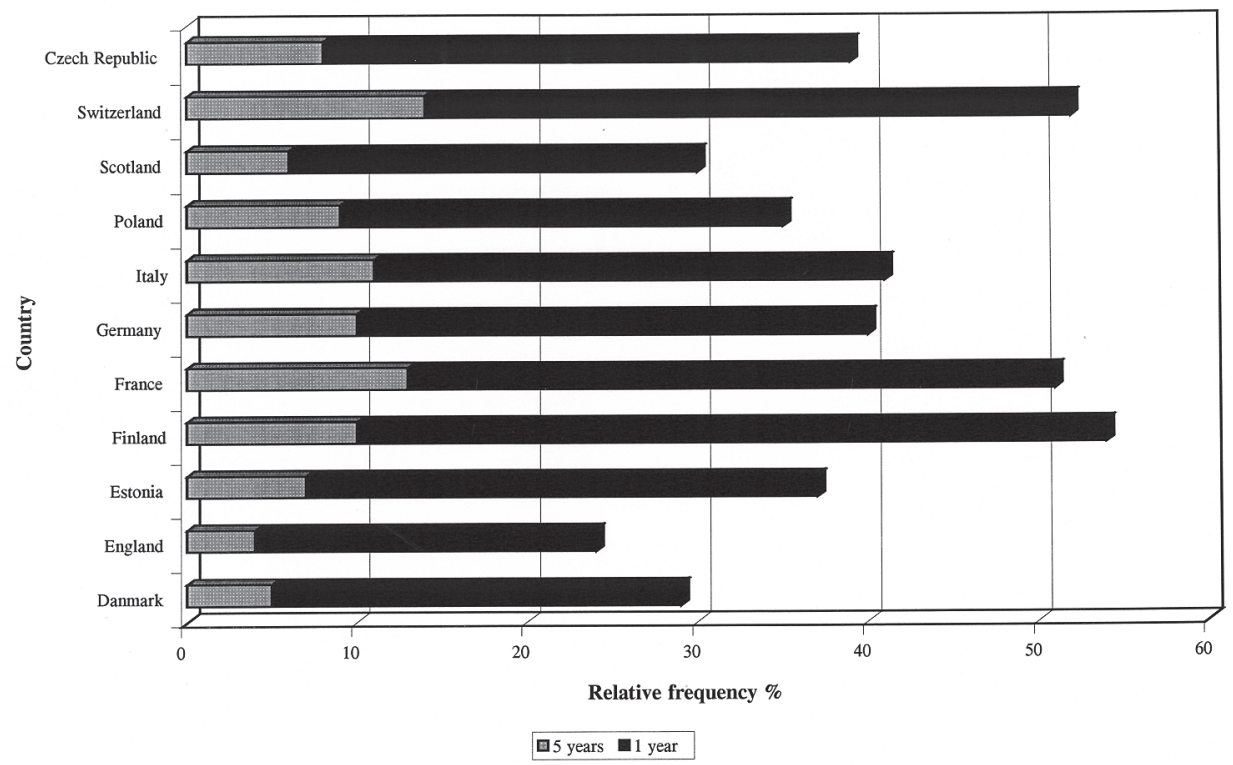

Graph 12. Age standardized lung carcinoma survival time in some European countries in 1995 - female

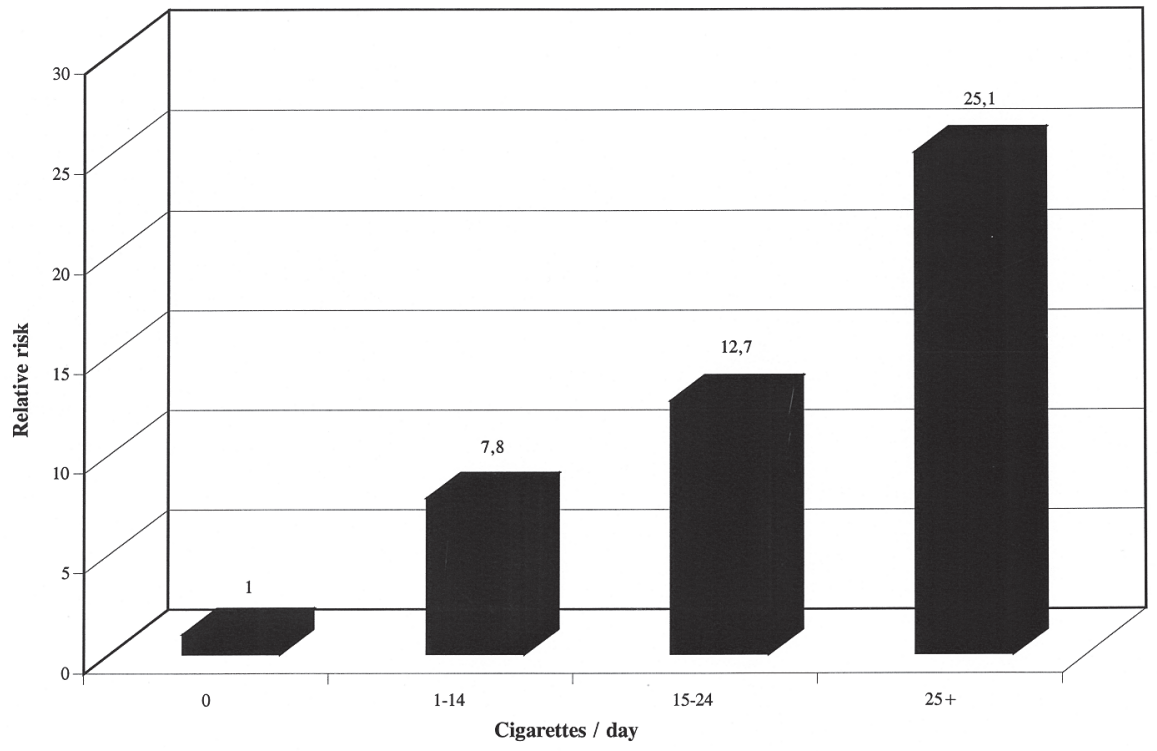

Graph 13. Relative risk in relationship to the number of cigarettes smoked per day

high as well, because the concentration of carcinogenic agents in the secondary stream is several times higher than in the main stream. This is due to incomplete combustion at lower temperature. An indicator for the solid part of the main stream and gaseous part of the secondary stream is nicotine, which we can evaluate in the environment. In case of an active, but also a passive smoker, exposure to tobacco smoke is evaluated by amount of nicotine and its main metabolite, cotinine ${ }^{19}$. An average smoker absorbs, while actively smoking, 20 to 30 cigarettes a day, $40 \mathrm{mg}$ of nicotine.

Lung cancer development is a long process that takes two, three and even more decades to develop ${ }^{21}$.The daily action of carcinogenic agents, meaning cigarette smoke, is needed for the lung cancer to develop. The bronchial epithelium gradually goes through the stages of metaplasia, dysplasia and carcinoma in situ which are reversible, providing the smoking is stopped before the process gets into the invasive stage. Another significant condition is the number of cigarettes smoked daily, depth of smoke inhalation into lungs ${ }^{22,}{ }^{23}$, age when smoking started, number of smoking years ${ }^{24}$ and the amount of tar contained in the cigarettes ${ }^{25}$. Risk of the lung cancer development for smokers who smoke 40 or more cigarettes a day is 20 times greater than for nonsmokers. The situation for women is slightly different. According to the study conducted in 1982-1986 among American women, the risk of lung cancer development was 12.7 for smoking women and this risk increased to 20 and more for women smoking more than 30 cigarettes a day ${ }^{22,23}$. (Graph 13). 
After quitting smoking, the risk of the lung cancer development decreases, even though, paradoxically, in the first years of abstinence the risk of the lung cancer development for the former smokers can be even higher than for continuing smokers. This can be explained by the fact that some smokers may have stopped smoking because of health problems that have been causing development of their lung cancer. A positive effect of the quitting of smoking can become apparent after 5 years, at the latest, when the relative risk is approximately 6 . Further abstinence results in further decrease of the risk which, however, never drops down to the risk level of persons who have never smoked, and even after 20 years of smoking abstinence, the relative risk is in the region of 1.1 to $2^{12,26,27}$ also in the relationship with the smoking period and the age of the smoker. (Graph 14)

Smoking promotes lung cancer development of all histological types but a greater effect is manifested with the squamous and small cell lung cancer ${ }^{28}$.

Risk of lung carcinoma development in the case of a non-smoker is rare even though it increases slightly with age ${ }^{29}$ and the incidence is up to about $10 \%$.

Incidence of lung cancer however is not completely explicable only as active smoking. The lung cancer is an illness with a multi-factorial etiology ${ }^{26,30}$. Even though active smoking has decisive importance, the significance of other factors cannot be disregarded, since, beside their independent effects, they can even increase the impact of smoking

\section{Passive smoking}

Passive smoking, meaning inhaling environmental tobacco smoke, is causing health damage and contributes to the increased incidence of the lung cancer among non-smokers ${ }^{31,32,33}$. A non-smoker, living or working in a smoke polluted environment for a prolonged period of time, is exposed to the 20 to $30 \%$ greater risk of lung cancer incidence in comparison with non-smokers who are not exposed to passive smoking ${ }^{34}$.

Tobacco smoke environment is mostly created by the secondary stream of smoke, which develops between two inhalations or by spontaneous smouldering of a cigarette stub. The temperature of the stub decreases to 300 ${ }^{\circ} \mathrm{C}$ or less and incomplete combustion of organic substances with chemical reactions under low combustion temperatures starts. In this secondary stream, which accounts for approximately $85 \%$ of the total amount of smoke, there is a several times higher concentration of carcinogenic agents than in the main stream. In such a secondary stream, there is for example, as compared with the main stream, 2.7 times more nicotine, 1.7 times more tar, 3.4 times more benzo-Apyran, 57 times more of specific tobacco nitrosamines and number of other substances. In the case of a nonsmoker, we assess his tobacco smoke exposure by the amount of present nicotine and his main metabolite cotinine ${ }^{35}$.

Even though it is difficult to determine the exact proportion of lung cancer due to passive smoking, it is estimated that the relative risk is 1.3 to $3.5^{36}$, depending on the time period and intensity of exposure. In the Czech Republic, it is estimated, that approximately 70 non-smokers die annually from the effect of passive smoking ${ }^{19}$.

\section{Risk factors of work environment}

Exposure to carcinogenic agents in the environment can affect the incidence of lung cancer independently of tobacco use, but in conjunction with smoking with low intake of protective substances in foodstuffs and in

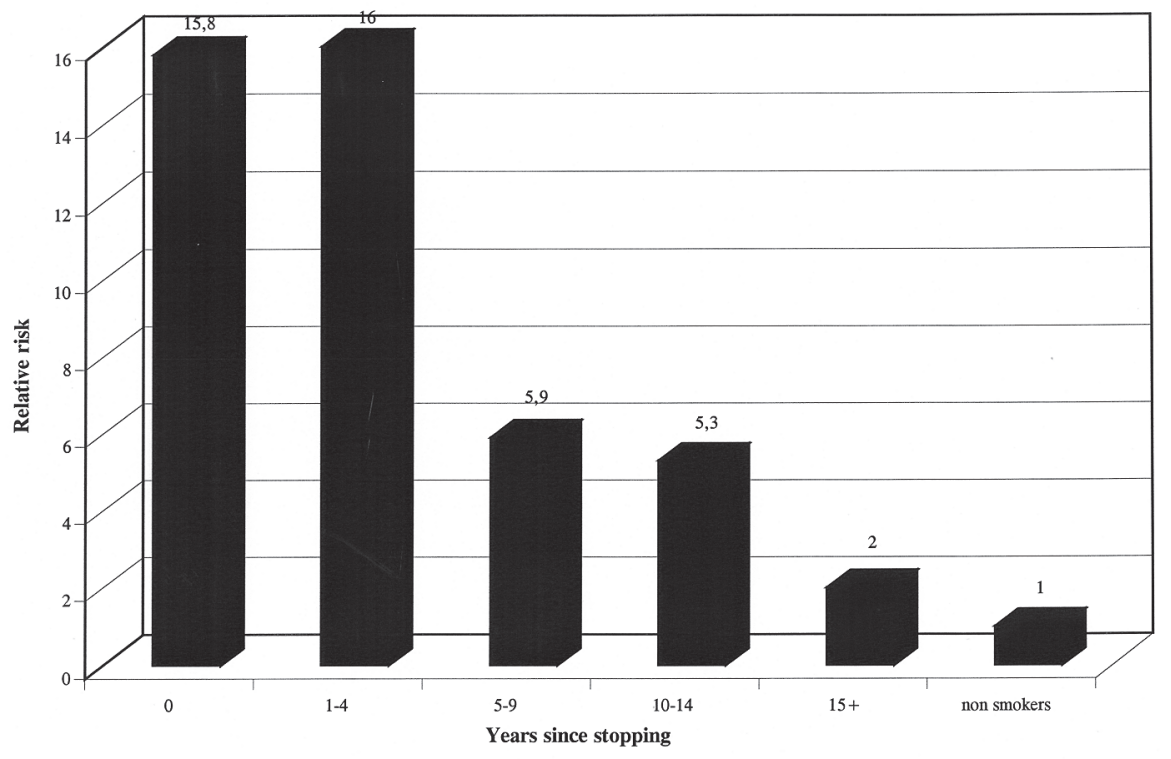

Graph 14. Relative risk for former smokers in relationship with the non-smoking period 
relationship to genetically determined susceptibility and resistance to carcinogenic stimuli, compounds the issue.

Elimination of exposure to carcinogenic agents in the work environment is conditioned by knowledge of sources of risk and compliance with the safety rules in work places, handling materials containing these substances. It is estimated that approximately $15 \%$ lung cancer cases are caused by exposure in working environments ${ }^{37}$.

Arsenic and its compounds, including pesticidal, insecticidal and herbicidal substances, for example, are classified as work environment risk factors ${ }^{38,39}$. Another work environment risk factor is asbestos. By this term we denote some types of filamentous mineral fibres differing in shape, length, flexibility and at the same time in aggressiveness of their biological action on organisms. Exposure to asbestos through air is considered one of the greatest risks of contracting the lung cancer and mesothelium in work environment ${ }^{40}$. Persons exposed to asbestos in work environments on a long term basis have up to $20 \%$ lung carcinoma death rate. The latency time is in the region of 15 to 20 years $^{41}$. Exposure to chromium, nickel, polycyclic aromatic hydrocarbons ${ }^{42}$, silicone compounds ${ }^{43}$, berylium, formaldehyde, ionizing radiation including radon and a number of others are considered risk factors for development of lung cancer ${ }^{44}$. Exposure to radon in work environment causes a significant increase in risk of development of lung cancer - about 13 times for non-smokers ${ }^{45}$ and 20 times for smokers ${ }^{46}$.

\section{Ionizing radiation in the environment and medicine}

Lung cancer is one of the main results of exposure to high doses of ionizing radiation ${ }^{47}$. Medicine itself is a source of about $15 \%$ of the total radiation load and the current trend rather points to an increase in this load. Therefore it is necessary to carefully consider the suitability and frequency of both X-Ray and isotopic diagnostic examinations. Of natural resources of ionizing radiation, radon, around $50 \%, 37,48$ and other emission of radioactive agents from subsoil of dwellings, building materials and water represent the largest proportion. Health consequences of radon radiation in dwellings in the Czech Republic are presently estimated $10 \%$ of all lung cancer cases, which means approximately 600 deaths annually as a result of radon radiation. The lung cancer caused by radon usually develops at a later age and does not develop at an early age and early adulthood.

\section{Air pollution}

Air pollution a suspect risk factor in lung cancer etiology $\mathrm{y}^{49,50}$.

The main source of contaminating substances emission into the atmosphere are combustion processes, that include electric energy production, thermal energy and transportation. Further sources are industrial and agricultural production.
Beside the outside atmosphere, a person is exposed to contaminating substances also in environment inside buildings, emitted from subsoil and building materials (radon), furnishing ( coating, formaldehyde) and outside atmosphere.

The proportion of carcinogenic agents in contaminated atmosphere is much smaller than other possible, already mentioned, factors. The seriousness, however, is increasing currently, with an ${ }^{37,49,51}$ accumulation of risk factors and thus increase in total load. The impact of polluted environment on total tumorous illnesses death rate is estimated approximately 2 to $3 \%{ }^{50}$.

\section{Nutrition}

Nutritional factors can intervene in the cancerogenic process at all stages. They interact, on the one hand, with individual chemical substances, and on the other hand through food and food groups in relationship to other outside environmental factors, second they interact within the scope of genetic peculiarities and individual susceptibility. Recent epidemiological studies indicate that dietetic and nutritive factors can positively influence the risk of lung cancer development ${ }^{52,53,54}$. This influence is possible in the sense of both, acceleration and inhibition of cancerogenesis. In cells, peculiar malignant proliferations have been found indicating genes - oncogenes, which can be activated through specific factors in the outside atmosphere. Current knowledge regarding the initiation, maintenance and regulation of oncogenes make it possible to claim that a greater part of malignant tumorous illnesses have an outside cause and can be, at least partially, prevented. The number of tumorous cells increases during the latency period, which can last 5 or more years. Considering the long lung cancer latency period, it is necessary to monitor the relationship between the nutrition and development of the illness during the foregoing 10-20 years before clinical detection of lung cancer.

High consumption of fats, food rich in cholesterol, including full-cream milk and eggs, increase the risk of lung cancer development ${ }^{54,55}$.

Also, consumption of alcohol can increase the risk of lung cancer development ${ }^{56,57}$. Alcoholic beverages have been classified as first class carcinogens for humans $^{58}$. A number of possible mechanisms are responsible for the carcinogenic effect of alcoholic beverages, firstly it is the nutritional deficiency, second an increased permeability of the bronchiol mucosa, leading to, possible penetration of other carcinogenic agents and also the presence of carcinogenic agents in alcoholic beverages. Excessive consumption of alcohol is hazardous primarily in combination with smoking because it strengthens the negative effect. The effect of alcohol itself is difficult to establish, because population groups of non-smoking alcohol users are very small and difficult to identify.

Other important components of food are vitamins and minerals. In vitamins contained in normal food, 
a protective effect against lung cancer has been confirmed. These are especially carotenoids, vitamins C and vitamins $\mathrm{E}$ and trace elements like selenium and zinc $^{59}$. Mechanism of the beta-carotene effect is related to the role of these agents in the cell differentiation and especially their anti-oxidizing effect, when they decrease lipid peroxidation and the creation of free oxygen radicals, this may also cause regression of bronchial dysplasia.

By contrast, vitamins in purified supplementary form appear to be non-effective and some studies, that were supposed to verify the protective effect of vitamin preparations, have found an increased risk of the lung cancer development after beta-carotene had been ta$\mathrm{ken}^{59,60}$. This is the reason why a supplementary carotene is not recommended.

Fruit and vegetables generally decrease the risk of tumorous illnesses and have a positive effect on lung cancer too. We can consider that the positive effect of fruit and vegetables can be achieved by a combination of known nutritional components (fiber, vitamins and mineral substances) and other bioactive agents, so called phytochemicals. This complex of positive factors works together and is not replaceable by isolated preparations. Approximately 20 to $30 \%$ of the lung cancer cases are preventable by nutritional factors.

Some studies have pointed to the relationship of the Body Mass Index (BMI) with the risk of development of the lung cancer. A significantly higher incidence of lung cancer in thinner persons, with a lower BMI, has been found ${ }^{61}$. Normal BMI values are considered values in the range of 19-25, the values BMI $<19$ mean underweight, the values in the range of 25-30 are considered as overweight and the values BMI > 30 are considered as obesity ${ }^{62}$.

\section{Primary non-tumorous lung illnesses}

Some primary non-tumorous illnesses (asbestosis, silicosis, tuberculosis, chronic bronchitis, pneumonia, emphysema and others) increase the relative risk of lung cancer development ${ }^{63}$, 64 , ranging from 1.5 for pneumonia to 2.7 for asthma bronchiale ${ }^{63}$.

\section{Genetic and hormonal effects}

Susceptibility and resistance to carcinogenic stimuli and the transformation process from a normal to a tumorous cell has a genetic basis. In susceptible persons, a different process of metabolism of carcinogenic and some other agents has been demonstrated ${ }^{65,66,67}$. Disorder in the ability to repair genic or chromosomal defects can be inherent.

The function of genetic factors is however weakened by strong environmental risk factors like smoking. While searching for genetic susceptibility markers, a genetically regulated enzymatic defect, which change the metabolism of polycyclic aromatic hydrocarbons (PAH) has been indicated. It has however been impossible to demonstrate this defect consistently ${ }^{68}$. In 1991, infor- mation concerning the DNA of polymorphism in a gene for cytochrome P450 (CYP1A1), that is responsible for benzo(a)pyrene, was published. In genetically susceptible persons, small doses of cigarette smoke exposure were sufficient for inducing squamous cell carcinoma of the lung ${ }^{69}$. However, even these findings were not always consistent. Further, in connection with the risk of the lung cancer development, the genetically controlled ability to metabolize anti-hypertensive agent debrisoquine was mentioned. P450 gene ( CYP 2D6), regulating debrisoquin metabolism, can also influence the metabolism of NNK nitrosamine, which is a potential lung carcinogen in experimental animals and which increases the risk of lung cancer development 6 times or more ${ }^{70}$. Also decreased activity of the glutathione S-transferases enzyme, (GST), which catalyzes polycyclic aromatic hydrocarbons (PAH) conjugation is mentioned as a factor which increases the risk of lung cancer development ${ }^{71}$. Recently, the function of polymorphism in the GSTM4 gene in assessing the risk of the lung cancer development, has been indicated ${ }^{72}$. GSTM1 deficit is associated with a relative risk of $1.4^{73}$. During development of lung cancer, a sequence of genetic changes can occur. Mutation in p53 suppressor gene tumour and in the oncogene ras is commonly found in lung tumorous tissue with the ras mutation limited to small-cell lung cancer ${ }^{74}$. The mutation frequency in lung tumorous tissue is still uncertain, but most tumours express mutated p53 genes and 20 to $30 \%$ of ras genes. Furthermore, p53 and ras mutations are usually found in the same tumour, which supports the idea that one increases the activity of the other in the carcinogenic process ${ }^{75}$.

Hormonal risk factors have been suggested by the observation that among nonsmokers adenocarcinoma affects proportionately more females than males, by the possible role of menstrual variables, particularly menstrual cycle length, and by the finding of sex steroid receptors in lung cancer ${ }^{76}$. It is also necessary to carry out a study of anti- tumour protective ability of an $\operatorname{organism}^{77}$.

A synergetic effect of several factors like smoking, exposure to contaminated work environment, polluted atmosphere, genetic pre-disposition and coincidence with previous lungs illness, especially with the lung adenocarcinoma.

\section{REFERENCES}

1. Čelko AM (1999) Epidemiologie v onkologii. Triton, Praha, 8.

2. The World Health Report 1995 "Bridging the gaps" - report of the Director General, WHO, Geneva, 1995.

3. Peckham M, et all. Oxford Textbook of Oncology, Vol. 2, 1533, Oxford Medical publications, 1995.

4. ÚZIS ČR. Zdravotnická ročenka ČR 2000. Zdravotnická statistika, Ústav zdravotnických informací a statistiky ČR, Praha, 2001.

6. Erban J (1988) Epidemiologická situace rakoviny plic. Praktický lékař, 68, 405-407.

7. Coleman MP, Esteve J, Damiecki P, et al. (1993) Trends in cancer incidence and mortality, p.789, IARC Scientific publication No. 12., International Agency for Research on Cancer, Lyon, France. 
8. ÚZIS ČR. Novotvary 1998. Ústav zdravotnických informací a statistiky ČR, Praha, 2001.

9. Kubík A, Zatloukal P, Kříž J (1999) Vývoj úmrtnosti na plicní rakovinu v České republice v letech 1950-1995 a predikce do roku 2009, Čas. Lék. čes., 138, 310-315.

10. Parkin DM (1989) Trends in lung cancer incidence worldwide. Chest, 96, Suppl., 5S-8S.

11. Shopland DR, Eyre HJ, Pechacek TF (1991) Smoking-attributable cancer mortality in 1991: Is lung cancer now the leading cause of death among smokers in the United States? J Nat Cancer Inst, 83, 1142-1148.

12. Miller BA, Ries LAG, Hankey BF, et al. (1993) SEER Cancer Statistics Review 1973-1990. Bethesda, MD: NIH Pub. No. 93-2789.

13. IARC. (1986) Tobacco smoking: Monographs on the Evaluation of Carcinogenic Risk of Chemicals to Man, Vol. 38. Lyon: International Agency for Research Cancer.

14. Doll R, Hill AB (1952) A study of aetiology of carcinoma of the lung. British Medical Journal 2, 1271-1286.

15. Levin LI, Goldstein H, Gerhardt PR (1950) Cancer and tobacco smoking: A preliminary report. JAMA 143, 336-338.

16. Doll R, Peto R, Wheatley K, et al. (1994) Mortality in relation to smoking: 40 years' observations on male British doctors. Br Med J 309, 901-911.

17. Garfinkel L, Silverberg E (1991) Lung cancer and smoking in the United States over the past 25 years. Cancer Journal Clin., 41, 137-145.

18. Kubík A, Polák J, Reissigová J (1995) Patterns of cigarette sales and lung cancer mortality in some Central and Eastern European countries, 1960-1989. Cancer, 75, 2452-2460.

19. Kubík A, Reissigová J (1990) Nepříznivý vývoj úmrtnosti na plícní rakovinu v České republice. Čas. Lék. čes., 129, 1217-1223.

20. Králíková E, Kozák JT (2000) Kouření na pracovišti. Pracovní lékařství, 52, 85-89.

21. Kozák JT, et al. (1993) Rizikový faktor kouření. KPK, Praha, P. 242.

22. Walter SD, Kubík A, Parkin DM, et al. (1992) The natural history of lung cancer estimated from the result of a randomized trial of screening. Cancer Causes and Control, 3, 115-123.

23. Garfinkel L, Stellman SD (1988) Smoking and lung cancer in women: findings in a prospective study. Cancer Res 48, 6951-6955.

24. Doll R, Gray R, Hafner B, et al. (1980) Mortality in relation to smoking: 22 years' observations on female British doctors. $\mathrm{Br}$ Med J 1, 967-971.

25. Moolgavkar SH, Dewanji A, Luekbeck G (1989) Cigarette smoking and lung cancer: reanalysis of the British doctors' data. J Natl Cancer Inst, 81, 415-420.

26. Kaufman DW, Palmer JR, Rosenberg L, et al. (1989) Tar content of cigarettes in relation to lung cancer. Am J Epidemiol, 129, 703-711.

27. Samet JM (ed.) Epidemiology of lung cancer. New York: Marcel Dekker, Inc. 1994. P. 544.

28. Freedman Da, Navidi WC (1990) Ex-smokers and the multistage model for lung cancer. Epidemiology, 1, 21-29.

29. Lubin JH, Blot WJ (1984) Assessment of lung cancer risk factors by histologic category. J Natl Cancer Inst, 73, 383-389.

30. Parkin DM, Sasco AJ (1993) Lung cancer: Worldwide variation in occurence and proportion attributable to tobacco use. Lung Cancer, 9, 1-16.

31. Davila DG, Williams DE (1993) The etiology of lung cancer. Mayo Clin. Proc., 68, 170-182.

32. Nilson R (2001) Environmental tobacco smoke revisited: the reliability of the data used for risk assessment. Risk Anal, Aug; 21(4), 737-760.

33. Trichopolous D, Kalandini A, Sparros L, et al. (1984) Passive smoking and lung cancer. Lancet, 1, 684.

34. Rachtan J (2002) Smoking, passive smoking and lung cancer cell types among women in Poland. Lung cancer, 35(2), 129-136.

35. Environmental Protection Agency: Respiratory health effects of passive smoking: lung cancer and other disorders. Washington: Epa, 1992

36. Matějová H, Hrubá D (2002) Kotinin - biologický ukazatel expozice cigaretovému kouři. Hygiena, 45, 232-237.
37. Garfinkel L (1981) Time trends in lung cancer mortality among non-smokers and a note on passive smoking. J Natl Cancer Inst 66, 1061-1066.

38. Marel M, Melínová L, Štastný B, et al. (1996) Vývoj epidemiologických ukazetelů plicní rakoviny v České republice v letech 1970-1990. Čas. Lék. čes., 135, 487-492.

39. Lubin JH, Pottern LM, Blot WJ, et al. (1981) Respiratory cancer among copper smelter workers: recent mortality statistics. J Occup Med 23, 779-784.

40. Taylor PR, Qiao YL, Schatzkin A, et al. (1989) Relation of arsenic exposure to lung cancer among tin miners Yunnan Province, China. Br J Ind Med 46, 881-886.

41. Morgan RW (1992) Attitudes about asbestos and lung cancer. Am J Ind Med 22, 437-441.

42. Selikoff IJ, Hammond EC, Seidman H (1979) Mortality experience of insulation workers in the United States and Canada, 1943-1976, Ann NY Acad Sci 330, 91-116.

43. IARC. (1983) Polynuclear aromatic hydrocarbons. Monographs on the Evalution of Carcinogenic Risk of Chemicals to Man, Vol. 34. Lyon: International Agency for Research on Cancer, 1983.

44. IARC. 1987b: Silica and some silicates. Monographs on the Evaluation of Carcinogenic Risk of Chemicals to Man, Vol. 42. Lyon: International Agency for Research on Cancer, 1987.

45. Lubin JH, Qiao TL, Taylor PR, et al. (1990) Quantitative evaluation of the radon and lung cancer association in a case-control study of Chinese ti miners. Cancer Res 50, 174-180.

46. Roscoe RJ, Steenland K, Halperin W, et al. (1989) Lung cancer mortality among non smoking uranium miners exposed to radon daughters. JAMA 262, 629-633.

47. Samet JM (1989) Radon and lung cancer. J Natl Cancer Inst 81, 745-757.

48. Lubin JH, Boice JD (1989) Estimating Rn-induced lung cancer in the United States. Health Phys 57, 417-427.

49. Clarke RH, Southwood TRE (1989) Risk from ionizing radiation. Nature 338, 197-198.

50. Jedrychowski W, Beecher H, Wahrendorf J, et al. (1990) A casecontrol study of lung cancer with special reference to the effect of air pollution in Poland. J Epidemiol Community Health 44, 114-120.

51. Pope CA $3^{\text {rd }}$, Burnett RT, Thun MJ, et al. (2002) Lung cancer, cardiopulmonary mortality, and long-term exposure to fine particulate air pollution. JAMA Mar 6; 287(9), 1132-41.

52. Friberg L, Cederlof R (1978) Late effects of air pollution with specil reference to lung cancer. Environ Health Perspect 22, 45-66.

53. Ziegler RG, Mayne ST, Swanson CA (1996) Nutrition and lung cancer. Cancer Causes Control, 7, 157-177.

54. Takezaki T, Hirose K, Inoue M, et al. (2001) Dietary factors and lung cancer risk in Japabese: with special reference to fish consumption and adenocarcinomas. Br J Cancer, 84(9), 1199-1206.

55. Kubik A, Zatloukal P, Tomasek L, et al. (2001) Diet and the risk of lung cancer among women. A hospital-based case-control study. Neoplasma, 48(4), 262-266.

56. Shekelle RB, Rossof A, Stamler J (1991) Dietary cholesterol and risk of lung cancer: the Western Electric Study. Am J Epidemiol 134, 480-484.

57. Boffeta P, Ye W, Adami HO, et al. (2001) Risk of cancers of the lung, head and neck in patients hospitalized for alcoholism in Swedwn. Br J Cancer, Sep 1; 85(5), 678-682.

58. Rachtan J (2002) Alcoholic beverages consumption and lung cancer cell types among women in Poland. Lung Cancer, Feb; 35(2), 119-127.

59. Potter JD, McMichael AJ (1984) Alcohol, beer and lung cancer A meaningful relationship? Int J Epidemiol, 13, 240-242.

60. Omenn GS, Goodman GE, Thorquist MD, et al. (1996) Effects of a combination of beta carotene and vitamin A on lung cancer and cardiovascular disease. N Engl J Med, 334, 1150-1155.

61. Kudlová E (2000) Beta-karoten v prevenci civilizačních onemocnění. Čas. Lék. čes., 139, 86-87.

62. Knekt P, Heliovaara M, Rissanen A, et al. (1991) Leaness and lung cancer risk. Int J Cancer, 49, 208-213.

63. Bauer J (1994) Onkologie praktického lékaře. Anomal, Praha. P. 76-78. 
64. Alavanja M, Brownson R, Boice J, et al. (1992) Preexisting lung disease and lung cancer among nonsmoking women. Am J Epidemiol 136, 623-632.

65. Zatloukal P, Petuželka L (2001) Karcinom plic. Grada, Praha. P. 40.

66. Sellers TA, Elston RC, Srewart C, et al. (1988) Familial risk of cancer among randomly selected cancer probands. Genet Epidemiol 5, 381-391.

67. Amos CT, Caporaso N, Weston A (1992) Host Factors in lung cancer risk: a review of interdisciplinary studies. Cancer Epidemio Biomarkers Prev 1, 505-513.

68. McDuffie HH (1991) Clustering of cancer in families of patients with primary lung cancer. J Clin Epidemiol 44, 69-76.

69. Kakri NT, Pokela R, Nuutinen L, et al. (1987) Aryl hydrocarbon hydroxylase in lymphocytes and lung tissue from lung cancer patients and controls. Int J Cancer 39, 565-570.

70. Nakachi N, Imai K, Hayashi S, et al. (1991) Genetic susceptibility to squamous cell carcinoma of the lung in relation to cigarette smoking dose. Cancer Res 51, 5177-5180.

71. Hoffmann D, Hecht S (1985) Nicotine-derived N-nitrosamines and tobacco-related cancer: current status and furure directions. Cancer Res 45, 935-944.
72. Siedegard J, Pero PW, Miller DG, et al. (1986) A glutathione transferase in human leukocytes as a marker for the susceptibility to lung cancer. Carcinogenesis 7, 751-753.

73. Triantafillos L, Matthew W, Maloney P, et al. (2002) A T2517C polymorfism in the GSTM4 gene is associated with risk of developing lung cancer. Lung cancer 37, issue 2, 143-146.

74. McWilliams JE, Sanderson BS, Harris EL, et al. (1995) Glutathione S-Transferase M1 (GSTM1) deficiency and lung cancer risk. Cancer Epidemiol Biomarkers Prevention 4, 589-594.

75. Lehman TA, Bennet WP, Metcalf RA, et al. (1991) p53 Mutations, ras mutations, and p53-heat shock to protein complexes in human lung carcinoma cell lines. Cancer Res 51, 4090-4096.

76. Slebos RJ, Hruban RH, Dalesio O, et al. (1991) Relationship between $\mathrm{k}$-ras oncogene activation and smoking in adenocarcinomaof the human lung. J Natl Cancer Inst 83, 1024-1027.

77. Gao Y, Blot W, Zheng W, et al. (1987) Lung cancer among Chinese women. Int J Cancer, 40, 604-609.

78. Fraumeni JF, Wertelecki W, Blattner WA, et al. (1975) Varied manifestations of a familiar lymphoproliferative disorder. Am J Med 59, 45-151. 